\title{
AN EXAMINATION INTO EMPLOYEES' SELF-ESTEEM AND ORGANIZATIONAL COMMITMENT IN A NON-PROFIT ORGANIZATION
}

\author{
Tri Wulida Afrianty 1)*, Geby Mariska ${ }^{2)}$ \\ ${ }^{1,2)}$ Fakultas Ilmu Administrasi, Universitas Brawijaya \\ *Email: twulidafia@ub.ac.id
}

\begin{abstract}
Abstrak
Dengan mempertimbangkan bahwa penelitian tentang komitmen karyawan pada organisasi non-profit masih terbatas, maka tujuan penelitian ini adalah untuk mengidentifikasi faktor-faktor yang mempengaruhi self-esteem serta komitmen organisasional karyawan/anggota pada organisasi non-profit. The International Association of Students in Economic and Commercial Sciences (AIESEC) pada Universitas Brawijaya dipilih sebagai lokasi penelitian. Dengan menggunakan pendekatan kualitatif, data primer pada penelitian ini diperoleh melalui semi structured in-depth interview. Kami melakukan interview secara mendalam terhadap Vice President of Talent Management, Team Leader of Human Resource and Capacity Coordinator, dan 4 orang anggota AIESEC Universitas Brawijaya. Data dianaliasis dengan menggunakan bantuan software QSR NVivo 12. Hasil penelitian menunjukkan bahwa kesempatan belajar dan mengembangkan diri, rasa memiliki, serta loyalitas adalah faktor yang membuat karyawan/anggota tertarik untuk bergabung dan berkomitmen terhadap AIESEC. Selain itu, hasil penelitian ini juga menunjukkan bahwa karyawan memiliki tingkat komitmen afektif yang lebih tinggi dibandingkan dengan komitmen normatif maupun komitmen berkelanjutan. Di sisi lain, organisasi melakukan banyak upaya untuk mempertahankan karyawan/anggotanya, diantarnya dengan memberikan apresiasi terhadap hasil kerja karyawan/anggota serta kegiatan Local Committee (LC).
\end{abstract}

Keywords: Self-Esteem, Komitmen Organisasional, Social Exchange Theory, Non-Profit Organization 


\section{INTRODUCTION}

Non-profit organizations (NPOs) are highly developed these days. United Nations, Save The Children, Ted Talks, Green Peace, and World Wildlife Fund are a few examples of various non-profit organizations spread all over the world with multiform social and humanitarian missions. One of the largest organizations that have been long established since the World War II and still operating until now is the International Association of Students in Economic and Commercial Sciences (AIESEC). AIESEC is a non-political, independent, not-forprofit organization run by university students and fresh graduates. Its member are young people who are interested in world issues, leadership and management, which makes this organization has its own characteristics.

Organizations must consider their employees as assets and have to keep in mind that employees are precious and could be a source of competitive advantage. Thus, organization need to find ways to retain their valuable employees. According to the social exchange theory (Blau, 1964), the opportunities provided by the organization make the employee feel obligated to give something back to the organization. Hence, it is beneficial for organizations to comprehend the employees' needs. As the nonprofit sector has become more professionalized and specialized in terms of training, development, and identity, the need to conceive issues and employee motivation is essential to improve both the employee management and the organizational strategies. It is undeniable that in fact, non-profit organizations are interconnected with for-profit and public organizations. Practically all over the world, non-profit organizations are agents of change for a better society's way of life. Thus, public and for-profit organizations usually collaborate with non-profit organizations to achieve mutual benefits. Nonprofit organizations generally have social missions and act as proponents and obtain services for their clients or members. NPOs are at their most effective when the people involved share common values and assumptions about the organization's purpose and its style of operation (Hudson, 1999). Committed and energetic volunteers are beneficial asset to NPOs. Although volunteers work for an organization without remuneration, they are likely to have unique expectations or beliefs concerning the organization. For instance, volunteers may expect some deep-seated accolades from the organization. Philips and Philips (2010) found that individuals can volunteer to improve their personal satisfaction as well as increase their self-esteem.

For an adult in the workplace, self-esteem appears to depend on three variables: self concept, feelings of self worth derived from one's job and feelings of self-worth related to one's personal life (Barefield, 1983). A suffice level of self-esteem in the people who make up an organization is fundamental for its effectiveness. Bandura (1977) proposed that people with the consciousness of greater selfefficacy and higher self-esteem normally have higher performance standards and goals, show more positive job attitudes and provide greater effort to accomplish challenging tasks (Katzel and Thompson, 1990). These positive attitudes and behaviours result in an increased commitment to the organization's performance (Muse and Stamper, 2007). Commitment is an emotional necessity and committed people feel obligated and responsible for what they do. Committed people in organizations are tied intellectually and emotionally to the values and purposes of the organization.

Research on the motivations and choice of career paths of individuals in the public and forprofit sectors has been widely done (Rainey and Steinbauer, 1999; Park and Rainey, 2007; Perry and Wise, 1990; Boyne, 2002; Wright, 2001). However, very few studies have examined the motivation of non-profit employees to choose careers serving their communities and what make them committed to the non-profit organization (Word and Park, 2015). Thus, the purpose of this research is to identify the individual reasons to be a member of a nonprofit organization. Specifically, we conducted this research to analyze the factors that affect employees' self-esteem and organizational commitment in a non-profit organization and examining the attempts implemented by the nonprofit organization to improve their employees' self-esteem and organizational commitment. Moreover, for the purpose of our study, we choose AIESEC at Brawijaya University, a state University in Indonesia, as our case study. The Brawijaya University AIESEC has established since 1987 and is second oldest AIESEC in 
Indonesia. In recruiting their members, AIESEC believes to anyone who believes in the AIESEC vision, supports its mission, and lives by the AIESEC values. AIESEC empowers young people to build a strong foundation of core values as they develop into responsible and entrepreneurial young leaders.

\section{LITERATURE REVIEW}

\section{Non-Profit Organization}

Wolf (1999) stated the term NPO connotes an entity that does not generate and share profit. These organizations are sometimes defined as third sector, as a complement to public and private sector. Mission is critical component that differentiates non-profit from for-profit organization. For profit entities engage in commercial activities to maximize profit for the owners and profit is given to the shareholders; while in NPOs, ownership is hard to define. Although non-profits do sometimes have surplus, it is either ploughed back to the entity, or transferred to other NPOs in case of liquidation. It is the unique characteristics of non-profits that attract volunteers and employees to NPOs. Frumkin (2002) listed the characterized non-profits as: (1) organizations that do not share profits to shareholders, (2) with no forceful participation, and (3) blurring line of ownership and accountability (Frumkin, 2002, p. $3)$.

NPOs rely upon volunteers to assume both operational and leadership responsibilities (Bowers, 2012). Volunteer leaders count on other volunteers to perform tasks and accomplish goals, these volunteers are motivated by potential rewards and benefits other than monetary compensation, and volunteer leaders often have fewer resources at their disposal (Pearce, 1982; Rowold and Rohmann, 2009). Volunteer leaders provide both managerial and operational support to volunteer members (McClusky, 2002). Volunteer members have full-time careers and have professional and technical expertise. This suggests that less formal leadership that provides a great deal of autonomy and provides volunteers with the authority and power to perform specific responsibilities is more effective (Schmid, 2002).

Positive staff relations also fostered a sense of relatedness to the organization and its mission,
NIAGAWAN Vol 9 No 1 Maret 2020

increasing volunteer commitment (Shin $\&$ Kleiner, 2003). Shin and Kleiner (2003) found that rewards and recognition also contribute to a sense of connection to the overall organization and its mission. Houle, Sagarin, and Kaplan (2005) suggested volunteers have varying motives and their participation in volunteer activities satisfies one of six intrinsic motivations: (a) meeting altruistic values, (b) learning and understanding, (c) career building, (d) meeting social needs, (e) assuaging feelings of guilt, or (f) enhancing self-esteem.

\section{Social Exchange Theory}

Social exchange theory posits that any relationships among people are formed by the use of a subjective cost-benefit analysis and the comparison of alternatives (Blau, 1964). Social exchanges among individuals involve trust, not legal obligations (Stanford, 2008) and are built on a reciprocity principle (Lambert, 2000; Wang et al., 2011). The reciprocity principle is a universal principle which is based on two assumptions: "(1) people should help those who helped them, and (2) people should not injure those who have helped them" (Gouldner, 1960, p. 171). The theory emphazies the conditions under which individuals feel obligated to reciprocate when they benefit from other people, or other entities (Lambert, 2000). In the field of management and organisation, social exchange theory has been used by scholars to understand the relationship between employees and employers (Lambert, 2000). Specifically, the theory has been applied to make clear the rationale behind the formation of positive employee work attitudes and behaviours toward their organisations, which includes organizational commitment, organizational citizenship behavior, and goodwill at work, in response to beneficial actions taken by organisation that are directed to the employees (e.g., Allen, 2001; Kossek, Colquitt, \& Noe, 2001; Lambert, 2000; Wang, Lawler, \& Shi, 2011). The basic principle underlying social exchange theory is that a person who gives rewarding services to another forms a 'voluntary' obligation to the latter person. In return, the latter person must provide benefits to the person who gives the services. If both parties value what they receive from the other, this exchange will continue (Blau, 1964). Thus, the application of social exchange theory suggests that if employees are treated favourably and if 
they gain benefits from their organizations (including non-profit organizations), employees will have a sense of obligation to exert positive work attitudes and behaviours. In the case of non-profit organization, if an individual has a need to volunteer and the organization provides an opportunity to do so, the individual should respond with a higher degree of positive work attitudes and behavior such as organizational commitment.

\section{Self-Esteem}

Self-esteem is a person's comprehensive evaluation of his or her worth, which is commonly come along with that person's attending to his or her qualities. Self-esteem exhibits one's attitude regarding self-acceptance, or non-acceptance. It is the degree to which a person believes in his or her capabilities, values, and achievements (Branden, 1982).Having high self-esteem evidently offers advantages to those who own it: They feel good about themselves, they are able to cope effectively with challenges and negative feedback, and they live in a sphere in which they believe that people value and respect them.Baumeister (1998, p. 680-740) indicated that although there are negative consequences associated with having extremenly high self-esteem, most people with high selfesteem appear to lead happy and productive lives. By contrast, people with low self-esteem see the world through a more negative filter, and their general animosity for themselves colors their perceptions of everything around them. Self-esteem depends on the value or attitude one has toward oneself.

According to Herr, Cramer, and Niles (2004), high levels of unemployment have been associated with increased rates of chemical dependency, interpersonal violence, suicide, criminal activity, and admissions to psychiatric facilities. Clearly, individuals with a genuine sense of positive self-esteem infrequantly commit such acts. Thus, difficult career situations often translate to difficult life situations, and such situations will negatively impact a person's self-esteem. When people experience low self-esteem, they often struggle considering career options, implementing their career choices, or managing their careers once their choices have been implemented.

\section{Organizational Commitment}

Organizational commitment has been discussed and examined from many perspectives and has been a subject to different definitions and measurements. However, according to Mathieu and Zajac (1990), there is a common theme among the various definitions and measures of organizational commitment wherein organizational commitment is considered to be an individual attachment to the organization. One of the earliest approaches to explain the concept of organizational commitment is Becker's side-bet theory (Cohen, 2007). According to Becker (1960), side bets refer to 'consequence of the person's participation in social organizations', which could be in terms of time, effort, money and skills. The theory posits that it is the individual side bets or the accumulated valued investment that makes the individual commited to the organization. If an individual leaves the organisation, these side bets would be lost. Thus, staying in the organization is the way to avoid both financial and non-financial losses (Becker, 1960).

In short, the side bets theory views a close relationship between organizational commitment and employees turnover (Cohen, 2007).

Porter and his colleagues (1974) offer an attitudinal approach in understanding organizational commitment (Cohen, 2007). According to Porter et.al (1974, p. 604) organizational commitment is defined as: "the strength of an individual's identification with and involvement in a particular organization. Such commitment can generally be characterized by at least three factors: (a) a strong belief in and acceptance of the organisation's goals and values; $(b)$ a willingness to exert considerable effort on behalf of the organisation; (c) a definite desire to maintain organisational membership".

One of the prominent works on organizational commitment was done by Meyer and Allen (1984). They suggested two dimensions of organizational commitment namely affective commitment and continuance commitment. The third dimension of commitment, which is normative commitment, was proposed a few years later (Allen \& Meyer, 1990; Meyer \& Allen, 1991). According to Allen and Meyer (1990, p. 1), affective commitment refers to 
"employees' emotional attachment to, identification with, and involvement in, the organisation". Continuance component refers to "commitment based on the costs that employees associate with leaving the organisation". Normative commitment refers to "employees' feelings of obligation to remain with the organisation". The measure of Allen and Meyer's three components of organisational commitment is also not without criticisms. However, to date, the approach has become the dominant approach in studying organizational commitment (Cohen, 2007; Shen \& Zhu, 2011). Off all components of organizational commitment, affective commitment has shown the strongest correlation with desirable organizational outcomes (Afrianty, Burgess, and Issa 2015). Hence, organizational typically strive to foster this type of commitment from their employees. This research also utilised the Allen and Meyer's measure to identify the AIESEC members' organizational commitment.

\section{RESEARCH METHODS}

This research can be classified into phenomenological research with qualitative approach. The research was conducted at AIESEC Local Committee of Universitas Brawijaya. The data mainly gathered through semi-structured in-depth interviews. To ensure the valid data, a triangulation method was applied, in which we compared interview results obtained from each interviewee as a comparison. We also compared the primary data gained through interviews with the secondary data gatherd from the organization's archives.

\section{RESULTS AND DISCUSSION}

\section{Factors Affecting Employees' Self-Esteem}

Chart 1. The Interview Results of Factors that Influence Employees' Self-Esteem

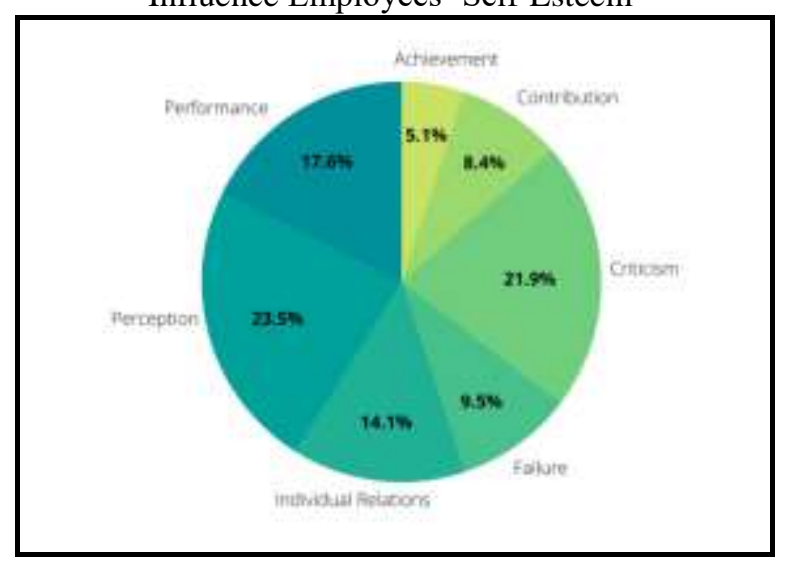

As can be seen on chart. 1, the main factor that influence the level of employees' self-esteem is the perception of others with a percentage of $23.5 \%$. Employees tend to worry about what other people think of them. They are very concerned about how other people see them as an individual, and are afraid when other people have an awful perception about them. Thinking of poor judgment about themselves can make employees lose their self-esteem, or in other cases, build up their motivation. Associated with the factor mentioned earlier, criticism also affects a person's self-esteem with a percentage of $21.9 \%$. Similar to perception from others, there are two circumtances that may occur due to criticism. Employees are able to make criticism as a motivation to try harder and bring the best results, or even make them lose enthusiasm and feel that what they have done is wasted. Another dominant factor is the performance of the employee itself, with a percentage of $17.6 \%$. If the performance of the employee is not optimal, or they did not get decent results, employees tend to lose their self-esteem. Beside the three main factors mentioned above, there are several other factors that also influence the level of employee self-esteem, including, relationships with fellow employees, failure, member contributions to events organized by AIESEC Universitas Brawijaya, and achievements. 


\section{Factors Affecting Employees' Organizational Commitment}

Chart 2. Types of Employees' Organizational Commitment

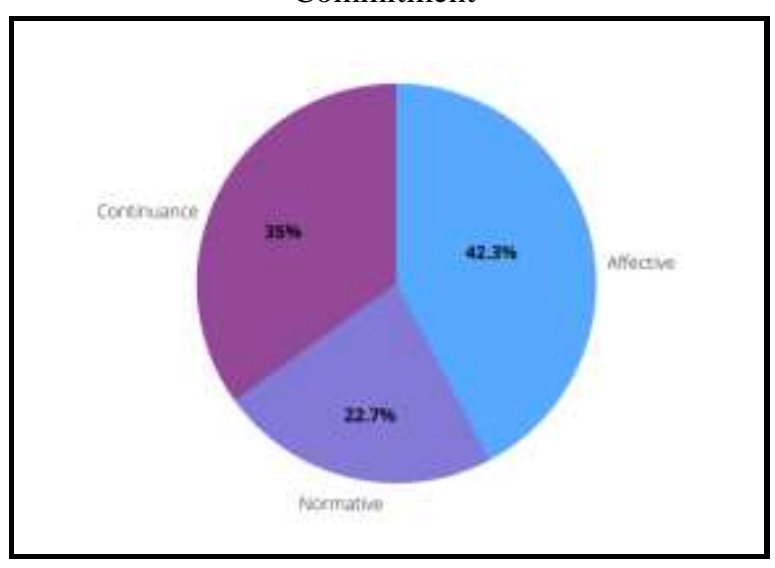

As can be seen on chart 2, affective commitment is the dominant type of organizational commitment possessed by AIESEC Universitas Brawijaya members with a percentage of $42.3 \%$. Followed by continuance commitment with a percentage of $35 \%$, and normative commitment with a percentage of $22.7 \%$.

Chart 3. The Interview Results of Factors Affecting Employees' Organizational Commitment

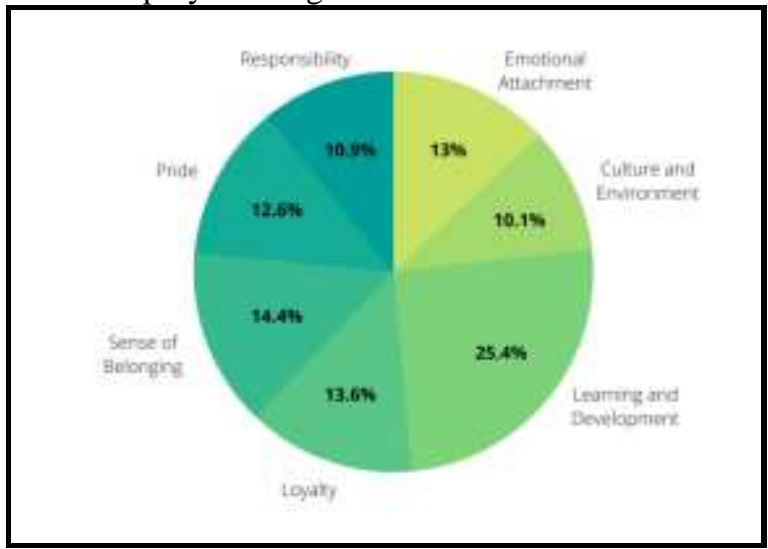

As can be seen on chart 3, the biggest factor arousing organizational commitment of employees at AIESEC Universitas Brawijaya is learning and development with a percentage of $25.4 \%$. The employees assume this organization provides what they need and help them to grow also develop them into a better person. Employees said that AIESEC really helps them to build networks and work professionally without leaving relationships with others. The employees believe that they will get more development if they stick around. Another significant factor is sense of belonging with a percentage of $14.4 \%$. Employees tend to choose to stay in the organization because they have a strong sense of belonging and feel emotionally
NIAGAWAN Vol 9 No 1 Maret 2020

attached to this organization. Along with the factors mentioned earlier, one of the factors that also influence the level of work commitment of AIESEC Universitas Brawijaya employees is loyalty with a percentage of $13.6 \%$. They believe that someone must be loyal to their organization. Employees thinks that if they have loyalty to an organization, all existing problems will be easier to pass. Beside the previous factors, there are several other factors that also affect work commitment levels of employee in AIESEC Universitas Brawijaya, including emotional attachment, pride, responsibility, and organizational culture and environment.

\section{Organization's Attempts to Increase Employees' Self-Esteem}

Chart 4. The Interview Results of Organization's Attempts to Increase Employees' Self-Esteem

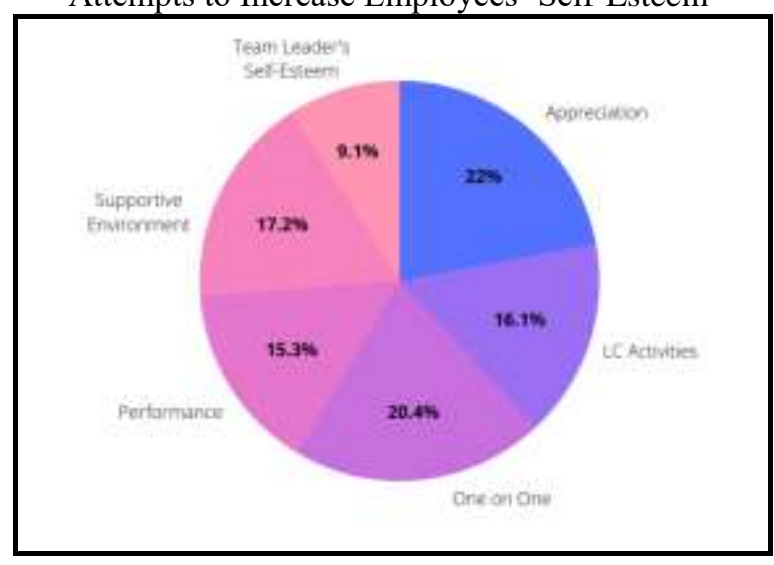

The information obtained from the interviews as can be seen on chart 4 , among all the attempts implemented by AIESEC Universitas Brawijaya, the most influential organizational strategy to improve self-esteem is through appreciation. Appreciation is very important no matter how big or small the achievements are. By giving appreciation to its employees, it will provoke them to do their best. However, employee suggests AIESEC to make more structured and more professional training, not only from the team leaders, but also from trainer/coach/psychologist. 


\section{Organization's Attempts to Increase Employees' Organizational Commitment}

Chart 5. The Interview Results of Organizational Attempts to Increase Work Commitment Levels of Employees

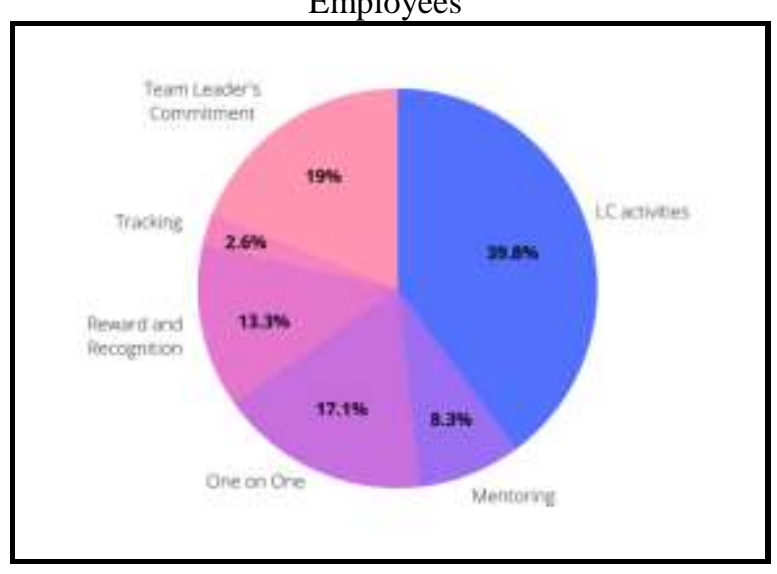

The interview results on chart 5 shows that among all the attempts implemented by AIESEC Universitas Brawijaya, the most influential organizational strategy to increase work commitment is through LC activities, such as LC bonding, LC gathering, conference, etc. The employees also agree that AIESEC needs more events and clarify its purpose so that the members themselves feels important to get involved. Relations between departments must be strengthened in order to increase the commitment of employee and these kind of events can help strengthen relationship between each department. However, the awareness of each member to contribute is also needed. Personal approach from other team leaders need to be done. Because if the approachment is from their own team leader only, their commitment will only be to their department, not to the organization.

\section{CONCLUSSION \\ Conclusions}

In terms of self-esteem, it is shown from this research that others perceptions, criticism, and performance are three biggest factors that can affect self-esteem of AIESEC Universitas Brawijaya's employees. Moreover, other factors that could also influence the employees' selfesteem, includes relationships with fellow employees, failure, member contributions to AIESEC events, and achievements.

Based on Allen and Meyer's components of organizational commitment, employees in this organization tend to have affective commitment. The main factors that underlie employees' commitment to AIESEC Universitas Brawijaya
NIAGAWAN Vol 9 No 1 Maret 2020

includes learning and development, sense of belonging, and loyalty. Besides, there are also a few other factors that can affect employees' commitment that are pride, organizational culture and environment, responsibility, their involvement in AIESEC events, emotional attachment, their intention to join the organization as well as sincerity.

There are several attempts made by AIESEC Universitas Brawijaya to improve self-esteem of its employees. One of the most successful attempts is appreciation. In addition, local committee (LC) activities are considered crucial for enhancing the organizational commitment of AIESEC Universitas Brawijaya employees.

\section{Suggestions}

1. The organization is encouraged to have a better understanding of what is needed by its employees. The employees suggest organization to make more events, giving more appreciations, and conduct structured training so they can be more attached to the organization.

2. In a nonprofit organization, in order to achieve its purpose, it is necessary to eliminate the boundaries between members and their leaders and strengthen relationships between them, so that everyone feels involved and committed.

3. Companies can collaborate with non-for profit organizations like AIESEC for corporate social responsibility activities, such as teaching underprivileged children, fundraising, campaigns, and other environmental activities.

4. Considering there is still limited research on self-esteem and organizational commitment in a nonprofit organization, further research on this topic is needed.

\section{REFERENCES}

Afrianty, T. W. (2013). Work Life Balance Policies in the Indonesian Context. (November), 267. Retrieved from http://espace.library.curtin.edu.au/R?fu nc=dbin-jump-full\&local_base=gen01 era02\&object_id=199554 
Bandura, A. (1977). Self-Efficacy: Toward a Unifying Theory of Behavioral Change. Psychological Review. Vol. 84, No. 2, pp. 191-215

Barefield, R.F. (1983). Sele-Esteem in the Workplace. American Water WorksAssociation, Vol. 75, No. 12, pp. 600-603.

Baumeister, R.F. (1998). The Self. In D. Gilbert, S. Fiske, \& G. Lindsey (Eds.). The Handbook of Social Psychology. New York: Random House

Beck, K. \& Wilson, C. (2000) Development of Affective Organizational Commitment: A Cross-Sequential Examination of Change with Tenure. Journal of Vocational Behavior. Vol. 56, No. 1, pp. 114-136

Blau, P.M. (1964). Exchange and Power in Social Life. New York, NY: John Wiley and Sons

Caught, K. \&Shadur. (2000). The Measurement Artifact in the Organizational Commitment Questionnaire. Psychological Reports. Vol. 87, pp 777788

Cropanzano,R., \& Mitchell, M.S. (2005). Social Exchange Theory: An Interdisciplinary Review. Journal of Management. Vol. 31 No. 6, pp. 874-900

Frumkin, P. (2002). On Being Nonprofit.

Massachussetts: Harvard University Press

Herr, E.L., Cramer, S.H., \& Niles, S.G. (2004). Career Guidance andCounseling Through the Lifespan ( $6^{\text {th }}$ ed. $)$. New York: Pearson.

Houle, B. J., Sagarin, B. J., \& Kaplan, M.F. (2005). A Functional Approach to Volunteerism: Do Volunteer Motives Predict Task Preference?.Basicand Applied Social Psychology. Vol. 27 No. 4, pp. 337-344

Hudson, M. (1999). Managing without Profit. Penguin Books: London

Katzel, R. \& Thompson, D. (1990). An Integrative Model of Work Attitudes, Motivation and Performance. Human Performance. Vol. 3, pp. 63-85

Wang, X., Lia, J., Xia, D., \& Chang, T. (2010). The Impact Of Organizational Justice on Work Performance: Mediating Effects Of Organizational Commitment and Leader Member Exchange.
NIAGAWAN Vol 9 No 1 Maret 2020 International Journal of Manpower, 31(6), 660-677

Maxwell, J.C. (1999). The 21 Indispensable Qualities of A Leader: Becomingthe Person Others Will Want to Follow. Nashville: Thomas NelsonPublishers.

McClusky, J.E. (2002). Re-thinking Nonprofit Organizational Governance: Implications for Management and Leadership. International Journal of Public Administration. Vol. 25 No. 4, pp. 539-559

Meyer, J.P., \& Allen, N.J. (1997).

Commitment in the Workplace: Theory,Research, and Apllication. Thousand Oaks, CA: Sage.

Morrow, P.C. (1993). The Theory and Measurement of Work Commitment. JAI Press: Greenwich

Muse L.A., \& Stamper C.L. (2007) Perceived organizational support: Evidence for mediated association with work performance. Journal of Managerial Issues, Vol.19 No.4, pp. 517-535

Wolf, T. (1999). Managing A Nonprofit Organization in the Twenty-First Century. New York: Fireside Rockefeller Center 